\title{
THERMAL PROCESSING EFFECTS ON THE MICROBIOLOGICAL, PHYSICOCHEMICAL, MINERAL, AND NUTRACEUTICAL PROPERTIES OF A ROASTED PURPLE MAIZE BEVERAGE
}

\author{
PABLO A. RODRÍGUEZ-SALINAS ${ }^{1}$, DOLORES MUY-RANGEL ${ }^{2}$, VANIA URÍAS-ORONA ${ }^{3}$, \\ FRANCISCO ZAVALA-GARCÍA ${ }^{1}$, ÁNGELA SUÁREZ-JACOBO ${ }^{4}$, JOSÉ B. HEREDIA ${ }^{2}$, \\ WERNER RUBIO-CARRASCO ${ }^{2}$, GUILLERMO NIÑO-MEDINA ${ }^{1 *}$
}

\begin{abstract}
${ }^{1}$ Universidad Autónoma de Nuevo León, Facultad de Agronomía, Laboratorio de Química y Bioquímica, Francisco Villa S/N, Col. Ex Hacienda El Canadá, C.P. 66050. General Escobedo, Nuevo León, México

${ }^{2}$ Centro de Investigación en Alimentación y Desarrollo (CIAD), A.C., Coordinación Culiacán. Carretera Culiacán a El Dorado km 5.5, C.P. 80110. Col. Campo el Diez, Culiacán, Sinaloa, México

${ }^{3}$ Universidad Autónoma de Nuevo León, Facultad de Salud Pública y Nutrición, Laboratorio de Química de los Alimentos. Av. Dr. Eduardo Aguirre Pequeño y Yuridia, Col. Mitras Centro, C.P. 64460. Monterrey, Nuevo León, México

${ }^{4}$ Centro de Investigación y Asistencia en Tecnología y Diseño del Estado de Jalisco (CIATEJ), A.C., Unidad Noreste. Parque de Investigación e Innovación Tecnológica (PIIT), C.P. 66629. Apodaca, Nuevo León, México
\end{abstract}

*corresponding author: guillermo.ninomd@uanl.edu.mx

Manuscript received: January 2019

\begin{abstract}
Thermal processing treatment of a roasted purple maize beverage was shown to be effective for reducing the microbiological growth since, after thermal treatment, microbial development was not detected. Physicochemical parameters, soluble solids, $\mathrm{pH}$, and titratable acidity were not affected by the treatment, while $L^{*}, a^{*}, b^{*}, C^{*}$, and $h$ chromatic parameters showed statistical differences. However, the visual aspects were not affected by the different thermal processing treatments. In terms of mineral content, the main effects were observed on $\mathrm{Na}, \mathrm{Mn}, \mathrm{Cu}$ and $\mathrm{Zn}$ concentrations. The thermal processing treatments resulted in higher contents of total phenols, total flavonoids, and total anthocyanins, while condensed tannins were not detected following any of the treatments. HPLC analysis detected ferulic acid in all treatments. On the other hand, chlorogenic acid was detected only in the control, while caffeic acid was detected in all thermal treatments, which means that caffeic acid is released from chlorogenic acid by thermal processing. The DPPH and FRAP antioxidant capacity levels were higher following thermal processing treatment, while the ABTS assay showed a contrasting behaviour.
\end{abstract}

\section{Rezumat}

Procesarea termică a băuturilor pe bază de porumb este cunoscut a fi eficientă din punct de vedere microbiologic. Parametrii fizico-chimici, pH-ul şi aciditatea nu au fost afectate de procesul tehnologic, în timp ce parametrii cromatici ai $L^{*}, a^{*}, b^{*}, C^{*}$ și $h$ au prezentat diferențe statistice. $\mathrm{Cu}$ toate acestea, aspectele vizuale nu au fost afectate de diferite tratamente termice de procesare. În ceea ce privește conţinutul mineral, efectele principale au fost observate pentru Na, Mn, $\mathrm{Cu}$ și $\mathrm{Zn}$. Tratamentul termic a condus la creșterea fenolului, a flavonoidelor și a antocianilor totali, în timp ce taninurile condensate nu au fost detectate. Analiza HPLC a identificat acidul ferulic. Pe de altă parte, acidul clorogenic a fost detectat numai în probele martor, în timp ce acidul cafeic a fost identificat în toate probele analizate, ceea ce relevă că acidul clorhidric este eliberat din acid clorogenic prin procesare termică. Nivelurile antioxidante DPPH şi FRAP au fost mai mari după tratamentul termic, în timp ce analiza ABTS a prezentat un comportament contrastant.

Keywords: thermal processing, maize beverage, nutraceutical properties, physicochemical parameters, mineral content

\section{Introduction}

Beverages are by far the most active functional food category because of their convenience and ability to meet consumer demands in terms of container contents, size, shape, and appearance, as well as their ease of distribution and storage, including refrigerated and shelf-stable products. In addition, they are excellent delivery matrices for nutrients and bioactive compounds [8]. Cereals and their ingredients have been accepted as functional foods as they provide several healthpromoting components such as dietary fibre, proteins, minerals and antioxidants. Cereals are now employed in the preparation of foods that are similar in appearance to conventional foods. These foods are used in the normal diet but have an added advantage of aiding physiological functions along with providing nutrition [10].

Maize (Zea mays L.) is one of the most commonly consumed cereals in the world, and Mexico is the centre of origin, domestication, and diversification of this crop. Because of this, it is important for the diet, society, culture, and economy of this country [15]. 
Some Mexican maize types are native genotypes that produce yellow, black, purple, blue, red, and orange grains. Due to their contents of phenolic compounds and their antioxidant capacity levels, they have been suggested to have nutraceutical properties [11].

Also, the outer tissues of cereals are rich in phenolic acids [38], and in particular, the bran of maize has been shown to be one of the most abundant sources of ferulic acid [40]. In addition, pigmented maize genotypes are rich in flavonoid compounds, especially anthocyanins [34] which give them their particular pigmentation and have beneficial effects on human health [4]. In Mexico, there are diverse native pigmented maize genotypes, and generally, they are grown for self-supply of the rural communities where they are produced; thus, their nutritional and nutraceutical properties are unknown. The aim of this work was to evaluate the thermal processing effect on the microbiological, physicochemical, mineral and nutraceutical properties of a roasted purple maize beverage.

\section{Materials and Methods}

\section{Beverage formulation}

Maize grains of "Morado La Soledad" purple genotype were roasted at $145^{\circ} \mathrm{C}$ for $30 \mathrm{~min}$. After that, the roasted grains were milled and sieved to obtain a flour with particle size $<0.5 \mathrm{~mm}$ (using standard mesh size 35 ). In the first step of the beverage formulation, two phases were prepared separately. In phase one, maize flour was mixed with sugar, cinnamon, stevia, xanthan gum and carboxymethyl cellulose. In phase two, water and vanilla extract were mixed. The beverage was obtained by mixing vigorously the two phases for $5 \mathrm{~min}$ and finally submitted to thermal treatments. The composition of the maize beverage is shown in Table I.

\section{Table I}

Maize beverage formulation

\begin{tabular}{lc}
\hline \multicolumn{1}{c}{ Ingredient } & $\%$ \\
\hline Water & 94.83 \\
Maize flour & 2.37 \\
Sugar & 1.90 \\
Vanilla extract & 0.47 \\
Cinnamon & 0.14 \\
Stevia & 0.14 \\
Xanthan gum & 0.09 \\
Carboxymethyl cellulose & 0.05 \\
\hline
\end{tabular}

\section{Thermal treatments}

The treatments included a control (no thermal treatment) and three thermal processes: $63^{\circ} \mathrm{C}$ for $30 \mathrm{~min}, 73^{\circ} \mathrm{C}$ for $15 \mathrm{~min}$ and $85^{\circ} \mathrm{C}$ for $5 \mathrm{~min}$. Control and thermal treatments were placed in $200 \mathrm{~mL}$ threaded glass bottles and sealed with aluminium bottle caps and left to cool down at room temperature. Twelve hours after their preparation the microbiological, physicochemical parameters, mineral composition and nutraceutical properties of the beverages were measured.
Microbiological analysis

Microbiological analysis was carried out according to Suárez-Jacobo et al. [35] with minor modifications. Decimal dilution in peptone water solution was used for microbial counting. Aerobic mesophilic were incubated on plate count agar (PCA, Oxoid Ltd., Basingstoke, UK) incubated at $36^{\circ} \mathrm{C}$ for $48 \mathrm{~h}$. Lactobacilli were incubated on non-acidified Man-RogosaSharpe agar (MRS, Oxoid) at $37^{\circ} \mathrm{C}$ for $48 \mathrm{~h}$ with $5 \% \mathrm{CO}_{2}$ injection. Enterobacteriaceae were incubated on violet red bile glucose agar (VRBG, Oxoid) at $37^{\circ} \mathrm{C}$ for $24 \mathrm{~h}$. Moulds and yeasts were incubated on potato dextrose agar (PDA, Oxoid) with $10 \%$ tartaric acid (Oxoid) at $25^{\circ} \mathrm{C}$ for 5 days. For counting of total spores, maize beverage was heated at $95^{\circ} \mathrm{C}$ for $5 \mathrm{~min}$, cooled in ice and pours plated on plate count agar (PCA, Oxoid) and incubated for $48 \mathrm{~h}$ at $37^{\circ} \mathrm{C}$.

Physicochemical parameters

The soluble solids were measured placing two drops of sample in the prism of an Atago Master-M 2313 refractometer (Tokyo, Japan). For the measurement of $\mathrm{pH}$ and titratable acidity, $10 \mathrm{~mL}$ of sample was diluted with $40 \mathrm{~mL}$ of distilled water. The $\mathrm{pH}$ was read in a Corning, $440 \mathrm{pH}$ meter (Woburn, USA) and after that, samples were titrated with $0.1 \mathrm{M} \mathrm{NaOH}$ to a $\mathrm{pH}$ of 8.2 (malic acid as predominant) according to the Association of Official Analytical Chemists (AOAC) [3]. For colour determination, a $1.5 \mathrm{~mL}$ spectrophotometric cuvette was filled with sample, and colour was determined using a CR-20 Konica Minolta Color Reader (Tokyo, Japan). Chromatic parameters were obtained using $\operatorname{CIELAB}\left(L^{*}, a^{*}, b^{*}\right)$ and $\mathrm{CIELCH}\left(\mathrm{L}^{*}, C^{*}, h\right)$ colour systems according to Commission Internationale De L'ecleirage (CIE) [7]. $L^{*}$ defines lightness $(0=$ black, $100=$ white $), a^{*}$ indicates red (positive $a^{*}$ ) or green value (negative $a^{*}$ ) and $b^{*}$ indicates yellow (positive $b^{*}$ ) or blue value (negative $\left.b^{*}\right), C^{*}$ (chroma; saturation level of $h$ ) and $h$ (hue angle: $0^{\circ}=$ red, $90^{\circ}=$ yellow, $180^{\circ}=$ green, $270^{\circ}=$ blue). Colour view was obtained by online software ColorHexa colour converter using $L^{*}, a^{*}$, and $b^{*}$ values [6].

Mineral content

Mineral analysis was performed based on AOAC [3] methods using an Agilent Atomic Absorption 240FS spectrometer (Santa Clara, United States). Briefly, $5 \mathrm{~mL}$ of $3 \mathrm{M} \mathrm{HCl}$ was added to $50 \mathrm{~mL}$ of sample and digested-evaporated at boiling temperature until $20 \mathrm{~mL}$ of sample was obtained. Afterwards, samples were filtered and used for mineral analysis. Potassium and sodium were detected by emission at wavelengths of 589.6 and $769.9 \mathrm{~nm}$, respectively, while calcium, magnesium, iron, zinc, copper, and manganese were determined by absorption at wavelengths of 422.7, $285.2,248.3,213.9,324.7$, and $279.5 \mathrm{~nm}$, respectively. The results were expressed as milligrams per liter of sample $(\mathrm{mg} / \mathrm{L})$ based on calibration curves prepared with standards of each mineral ( 0 to $100 \mathrm{mg} / \mathrm{L}$ for 
FARMACIA, 2019, Vol. 67, 4

sodium and potassium; 0 to $10 \mathrm{mg} / \mathrm{L}$ for calcium, magnesium, iron and manganese; and 0 to $5 \mathrm{mg} / \mathrm{L}$ for zinc and copper).

Total phenols, total flavonoids, condensed tannins, and total anthocyanins

Total phenols, total flavonoids and condensed tannins were carried out according to López-Contreras et al. [19], while total anthocyanins content was measured according to Abdel-Aal and Hucl [1], all the assays were performed at room temperature. The content of total phenols was determined based on the $f$ Folin-Ciocalteu reaction. Briefly, $0.2 \mathrm{~mL}$ of sample was placed in $2.6 \mathrm{~mL}$ of distilled water, oxidized with $0.2 \mathrm{~mL}$ of Folin-Ciocalteu reagent and after $5 \mathrm{~min}$ neutralized with $2 \mathrm{~mL}$ of $7 \% \mathrm{Na}_{2} \mathrm{CO}_{3}$ solution. The reaction was left for 90 min in darkness and finally the absorbance of the sample was measured at $750 \mathrm{~nm}$. Gallic acid was used as the standard ( 0 to $200 \mathrm{mg} / \mathrm{L}$ ) and the results were expressed as milligrams of gallic acid equivalent per litre of sample (mg GAE/L).

The content of total flavonoids was evaluated based on the reaction of aluminium chloride. Briefly, $0.2 \mathrm{~mL}$ of sample extract was placed in $3.5 \mathrm{~mL}$ of distilled water, followed by $0.15 \mathrm{~mL}$ of $5 \% \mathrm{NaNO}_{2}$. After 5 min, $0.15 \mathrm{~mL}$ of $10 \% \mathrm{AlCl}_{3}$ was added and $5 \mathrm{~min}$ later $1.0 \mathrm{~mL}$ of $1 \mathrm{M} \mathrm{NaOH}$ was added. Samples were left for $15 \mathrm{~min}$ in darkness and finally their absorbance was measured at $510 \mathrm{~nm}$. Catechin was used as standard ( 0 to $200 \mathrm{mg} / \mathrm{L}$ ) and the results were expressed as milligrams of catechin equivalents per litre of sample (mg CatE/L).

The content of condensed tannins was determined based on the reaction of vanillin- $\mathrm{H}_{2} \mathrm{SO}_{4}$. Briefly, $0.25 \mathrm{~mL}$ of sample extract was mixed with $0.65 \mathrm{~mL}$ of $1 \%$ vanillin solution and $0.65 \mathrm{~mL}$ of $25 \% \mathrm{H}_{2} \mathrm{SO}_{4}$ (both dissolved in methanol). The samples were incubated $15 \mathrm{~min}$ at $30^{\circ} \mathrm{C}$ in darkness and finally the absorbance was measured at $500 \mathrm{~nm}$. Catechin was used as standard ( 0 to $200 \mathrm{mg} / \mathrm{L}$ ) and the results were expressed as milligrams of catechin equivalents per litre of sample (mg CatE/L).

For total anthocyanins content, $200 \mu \mathrm{L}$ of sample were mixed with $10 \mathrm{~mL}$ of ethanol-HCl (85:15 v/v, $\mathrm{pH} 1$, $4^{\circ} \mathrm{C}$ ) and shaken at $200 \mathrm{rpm}$ for $30 \mathrm{~min}$. Afterwards, the sample was centrifuged at $1000 \mathrm{rpm}$ for $15 \mathrm{~min}$ and finally the absorbance of $3.5 \mathrm{~mL}$ of sample was measured at $535 \mathrm{~nm}$. The content of anthocyanins was reported as milligrams of cyanidin-3-glucoside $(\mathrm{C} 3 \mathrm{G})$ equivalents per litre of sample (mg C3GE/L) using the following formula:

$\mathrm{C}=(\mathrm{A} / \varepsilon) *(\mathrm{~V} / 1000) * \mathrm{MW} *(1 /$ weight of sample $) * 10^{6}$, where: $\mathrm{C}=$ concentration in $\mathrm{mg} \mathrm{C} 3 \mathrm{GE} / \mathrm{L}^{1}, \mathrm{~A}=$ absorbance of sample, $\varepsilon=$ molar absorptivity ( $\mathrm{mg}$ $\mathrm{C} 3 \mathrm{GE}=26965 / \mathrm{cm} \times \mathrm{mol}), \mathrm{V}=$ volume of sample, $\mathrm{MW}=$ molecular weight of C3G $(449.2 \mathrm{~g} / \mathrm{mol})$.
High Performance Liquid Chromatography (HPLC) Analysis of Phenolics

The content of individual phenolics by HPLC were analysed according to Santos et al. [32]. The phenolic compounds were identified in an Agilent 1260 Infinity chromatograph equipped with autosampler (G1329B), quaternary pump (G1311C), thermostated column compartment (G1316A) and diode array detector (G4212B) (Agilent, Santa Clara, United States). The separation was carried out in an Agilent Zorbax Eclipse Plus C18 (5 $\mu \mathrm{m}, 100 \mathrm{~mm} \times 3 \mathrm{~mm})$ and the mobile phase consisted of a gradient mixture of water $(1 \%$ $\mathrm{HCl}$, solvent A) and methanol (1\% $\mathrm{HCl}$, solvent $\mathrm{B})$. The gradient used was: $0 \mathrm{~min}, 95 \% \mathrm{~A} ; 4 \mathrm{~min}, 95 \% \mathrm{~A}$; $20 \mathrm{~min}, 73 \% \mathrm{~A} ; 50 \mathrm{~min}, 5 \% \mathrm{~A} ; 57 \mathrm{~min}, 99 \% \mathrm{~A} ; 58$ $\min , 99 \% \mathrm{~A} ; 60 \mathrm{~min}, 95 \% \mathrm{~A}$. The flow rate was 0.7 $\mathrm{mL} / \mathrm{min}$, the injection volume of sample used was $10 \mu \mathrm{L}$ and all the samples were run at $25^{\circ} \mathrm{C}$. The detection of the phenolic compounds was recorded at $280 \mathrm{~nm}$ and the spectrum of each compound was recorded by a diode array from 200 to $400 \mathrm{~nm}$. Levels of phenolic compounds were calculated based on a calibration curve obtained with standards of caffeic acid, catechin, chlorogenic acid, coumaric acid, ferulic acid, gallic acid, quercetin and sinapic acid in concentrations from 0 to $160 \mathrm{mg} / \mathrm{L}$. The results were expressed as milligrams per litre of sample $(\mathrm{mg} / \mathrm{L})$ of each phenolic compound.

DPPH, ABTS, and FRAP antioxidant capacity DPPH (2,2-diphenyl-1-picrylhydrazyl), ABTS (3ethyl-benzothiazoline-6-sulfonic acid) and FRAP (Ferric Reducing Antioxidant Power) antioxidant capacity assays were carried out according to LópezContreras et al. [19]. The DPPH antioxidant capacity was evaluated using a working solution of $60 \mu \mathrm{M}$ (in $80 \%$ methanol) with the absorbance adjusted to 0.7 at $517 \mathrm{~nm}$. The assay was carried out by mixing $0.2 \mathrm{~mL}$ of sample with $3.3 \mathrm{~mL}$ of the DPPH working solution at room temperature, the reaction was left for $30 \mathrm{~min}$ in darkness and the absorbance was determined.

The ABTS (3-ethyl-benzothiazoline-6-sulfonic acid) antioxidant capacity was carried out using a working solution obtained by mixing one $\mathrm{mL} 7.4 \mathrm{mM}$ of ABTS and one $\mathrm{mL}$ of $2.6 \mathrm{mM}$ of $\mathrm{K}_{2} \mathrm{~S}_{2} \mathrm{O}_{8}$ and allowing them to react for $12 \mathrm{~h}$ in darkness. After that, the absorbance of the working solution was adjusted to 0.7 at $734 \mathrm{~nm}$ by diluting with methanol. The ABTS assay was performed by mixing $0.2 \mathrm{~mL}$ of sample with $3.3 \mathrm{~mL}$ of ABTS working solution at room temperature, reaction was left for $30 \mathrm{~min}$ in darkness and the absorbance of the sample was measured. The FRAP (Ferric Reducing Antioxidant Power) antioxidant capacity was determined using a working solution prepared by mixing $300 \mathrm{mM} \mathrm{C}_{2} \mathrm{H}_{3} \mathrm{NaO}_{2}$ * $3 \mathrm{H}_{2} \mathrm{O}$ (pH 3.6), $10 \mathrm{mM}$ TPTZ (2,4,6-tripyridyl-striazine, in $40 \mathrm{mM} \mathrm{HCl}$ ) and $20 \mathrm{mM} \mathrm{FeCl}_{3} * 6 \mathrm{H}_{2} \mathrm{O}$ in 10:1:1 (V:V:V:) proportion. The FRAP assay was prepared by mixing $0.2 \mathrm{~mL}$ of sample with $3.3 \mathrm{~mL}$ 
of FRAP working solution, the samples were left for $30 \mathrm{~min}$ in darkness at $37^{\circ} \mathrm{C}$ and their absorbance were registered at $593 \mathrm{~nm}$. Trolox (6-hydroxy-2,5,7,8tetramethylchroman-2-carboxylic acid) was used as standard (0 to $200 \mu \mathrm{mol} / \mathrm{L}$ ) for DPPH, ABTS and FRAP assays and the results were expressed as micromoles of Trolox equivalent per litre of sample ( $\mu \mathrm{mol}$ $\mathrm{TE} / \mathrm{L})$.

\section{Results and Discussion}

Microbiological analysis

The microbiological analysis of the control maize beverage (Table II) showed values of 7.31, 1.58, and $7.07 \log \mathrm{CFU} / \mathrm{mL}$ for aerobic mesophiles, lactobacilli and enterobacteria, respectively. All of the thermal samples treatments used showed a total inactivation of the microorganisms detected in the control treatment obtaining a lethality equal to and/or greater than that of aerobic mesophiles, lactobacilli, and enterobacteria.

Table II

Microbiological analysis of maize beverage samples

\begin{tabular}{lccccc}
\hline \multirow{2}{*}{ Treatment } & \multicolumn{5}{c}{ Microbial group $(\log \mathrm{CFU} / \mathrm{mL})$} \\
\cline { 2 - 5 } & Aerobic mesophiles & Lactobacilli & Enterobacteria & Moulds and yeasts & Spores \\
\hline Control & $7.31 \pm 0.04^{\mathrm{a}}$ & $1.58 \pm 0.02^{\mathrm{a}}$ & $7.07 \pm 0.04^{\mathrm{a}}$ & $\mathrm{ND}$ & ND \\
$63^{\circ} \mathrm{C}, 30 \mathrm{~min}$ & $\mathrm{ND}$ & $\mathrm{ND}$ & $\mathrm{ND}$ & ND & ND \\
$73^{\circ} \mathrm{C}, 15 \mathrm{~min}$ & $\mathrm{ND}$ & $\mathrm{ND}$ & $\mathrm{ND}$ & $\mathrm{ND}$ & ND \\
$85^{\circ} \mathrm{C}, 5 \mathrm{~min}$ & $\mathrm{ND}$ & $\mathrm{ND}$ & $\mathrm{ND}$ & $\mathrm{ND}$ & ND \\
\hline
\end{tabular}

The different letters in the columns indicate statistical difference $(p \leq 0.05, \mathrm{n}=3)$. ND $=$ not detected

Moulds, yeasts, and spores were not detected in any treatment. These results show that all heat treatment conditions had a lethal effect on the microorganisms in the beverage, and Suárez-Jacobo et al. [35] and Rico et al. [30] mentioned that the thermal treatment is effective for the beverage conservation due to the inactivation of pathogenic microorganisms and microorganisms responsible for the deterioration of food. Physicochemical parameters

The soluble solid value (Table III) in the maize beverages was statistically similar after the thermal treatments; the only observed difference was for the treatments at $85^{\circ} \mathrm{C}$ and $63^{\circ} \mathrm{C}$, which showed values of 2.03 and 2.23 , respectively. The $\mathrm{pH}$ values varied from 6.21 to 6.31 , and the titratable acidity value in all samples was $0.033 \%$ (Table III). Measured variables showed no difference $(\mathrm{p} \geq 0.05)$ related to the thermal process applied. Our results show that the thermal processes do not significantly modify soluble solids, the $\mathrm{pH}$, or the titratable acidity, as observed previously by Yusof and Chiong [39], Suárez-Jacobo et al., [35] and Zulueta et al. [41].

Table III

Analysis of soluble solids, $\mathrm{pH}$, and titratable acidity in maize beverage samples

\begin{tabular}{lccc}
\hline \multirow{2}{*}{ Treatment } & \multicolumn{3}{c}{ Physiochemical parameter } \\
\cline { 2 - 4 } & Soluble solids (\%) & $\mathrm{pH}$ & Titratable acidity (\%) \\
\hline Control & $2.17 \pm 0.058^{\mathrm{ab}}$ & $6.29 \pm 0.081^{\mathrm{a}}$ & $0.033 \pm 0.001^{\mathrm{a}}$ \\
$63^{\circ} \mathrm{C}, 30 \mathrm{~min}$ & $2.23 \pm 0.058^{\mathrm{a}}$ & $6.22 \pm 0.032^{\mathrm{a}}$ & $0.033 \pm 0.001^{\mathrm{a}}$ \\
$73^{\circ} \mathrm{C}, 15 \mathrm{~min}$ & $2.13 \pm 0.058^{\mathrm{ab}}$ & $6.24 \pm 0.006^{\mathrm{a}}$ & $0.033 \pm 0.001^{\mathrm{a}}$ \\
$85^{\circ} \mathrm{C}, 5 \mathrm{~min}$ & $2.03 \pm 0.058^{\mathrm{b}}$ & $6.21 \pm 0.036^{\mathrm{a}}$ & $0.033 \pm 0.001^{\mathrm{a}}$ \\
\hline
\end{tabular}

The different letters in the columns indicate statistical differences $(\mathrm{p} \leq 0.05, \mathrm{n}=3)$.

The chromatic variables in maize beverages showed statistical differences $(p \leq 0.05)$ among treatments for $L^{*}, a^{*}, b^{*}, C^{*}$, and $h$. The chromatic property values were as follows: $L^{*}$ : from 33.92 to $31.10, a^{*}$ : from 2.84 to 2.44 to $2.84, b^{*}$ : from 9.00 to $7.24, C^{*}$ : from 9.42 to 7.80 , and $h$ : from 72.44 to 70.10 (Table IV). For all chromatic properties, the control showed the highest values, while the $73^{\circ} \mathrm{C}, 15 \mathrm{~min}$ treatment showed the lowest values for $L^{*}, a^{*}, b{ }^{*}$ and $C^{*}$ and the $85^{\circ} \mathrm{C}, 15 \mathrm{~min}$ treatment showed the lowest value for $h$. It was observed that the values of chromatic properties decreased with the increasing temperature, which agrees with the results obtained by Cortés et al. [9] and Zulueta et al. [41], who reported changes in chromatic values in beverages after thermal processes.

Table IV

Chromatic properties in maize beverage samples

\begin{tabular}{lccccc}
\hline \multirow{2}{*}{ Treatment } & \multicolumn{5}{c}{ Chromatic property } \\
\cline { 2 - 6 } & $L^{*}$ & $a^{*}$ & $b^{*}$ & $C^{*}$ & $h$ \\
\hline Control & $33.92 \pm 0.13^{\mathrm{a}}$ & $2.84 \pm 0.05^{\mathrm{a}}$ & $9.00 \pm 0.07^{\mathrm{a}}$ & $9.42 \pm 0.04^{\mathrm{a}}$ & $72.44 \pm 0.21^{\mathrm{a}}$ \\
$63^{\circ} \mathrm{C}, 30 \mathrm{~min}$ & $32.26 \pm 0.15^{\mathrm{b}}$ & $2.44 \pm 0.11^{\mathrm{c}}$ & $7.42 \pm 0.08^{\mathrm{b}}$ & $7.84 \pm 0.11^{\mathrm{b}}$ & $71.80 \pm 0.70^{\mathrm{a}}$ \\
$73^{\circ} \mathrm{C}, 15 \mathrm{~min}$ & $31.10 \pm 0.68^{\mathrm{c}}$ & $2.58 \pm 0.16^{\mathrm{bc}}$ & $7.24 \pm 0.25^{\mathrm{b}}$ & $7.68 \pm 0.28^{\mathrm{b}}$ & $70.40 \pm 0.60^{\mathrm{b}}$ \\
$85^{\circ} \mathrm{C}, 5 \mathrm{~min}$ & $31.20 \pm 0.19^{\mathrm{c}}$ & $2.66 \pm 0.09^{\mathrm{ab}}$ & $7.32 \pm 0.08^{\mathrm{b}}$ & $7.80 \pm 0.10^{\mathrm{b}}$ & $70.10 \pm 0.41^{\mathrm{b}}$ \\
\hline
\end{tabular}

The different letters in the columns indicate statistical differences $(\mathrm{p} \leq 0.05, \mathrm{n}=3)$. 
However, we determined that browning was not caused by enzymatic reactions, since the thermal process temperatures inactivate oxidizing enzymes such as polyphenol oxidase, as described by Rico et al. [30], Jang and Moon [14] and Rawson et al. [28]. We attribute the browning to non-enzymatic reactions such as the Millard reaction and caramelization of the sugars in the sample, as reported by Ajandouz et al. [2], Tacora et al. [36], and Pérez-Hernández et al. [27]. Mineral content

The contents of the major minerals in the maize beverages following different thermal treatments did not show a statistical difference $(\mathrm{p} \geq 0.05)$ : $\mathrm{Ca}(209.65$ to $189.55 \mathrm{mg} / \mathrm{L}), \mathrm{Mg}$ (41.03 to $34.84 \mathrm{mg} / \mathrm{L}), \mathrm{K}$ (129.60 to $97.39 \mathrm{mg} / \mathrm{L}), \mathrm{P}$ (169.60 to $145.74 \mathrm{mg} / \mathrm{L})$,

and $\mathrm{S}(91.73$ to $83.76 \mathrm{mg} / \mathrm{L})$. For $\mathrm{Na}$, there was a statistical difference $(\mathrm{p} \leq 0.05)$ and values ranged from 254.27 to $200.43 \mathrm{mg} / \mathrm{L}$ (Table V). For the minor minerals, the observed values were as follows: $\mathrm{Mn}$ : from 0.36 to $0.15 \mathrm{mg} / \mathrm{L}, \mathrm{Cu}$ : from 0.34 to $0.18 \mathrm{mg} / \mathrm{L}$ and $\mathrm{Zn}$ : from 0.72 to $0.25 \mathrm{mg} / \mathrm{L}$. In addition, Fe values ranged from 3.87 to $2.11 \mathrm{mg} / \mathrm{L}$, and the thermal treatment results were not statistically different $(\mathrm{p} \geq$ 0.05 ) (Table VI). The contents of major and minor minerals indicate that the formulated maize beverage is an excellent source of minerals, which are essential for daily intake as an important part of human nutrition. These inorganic elements are required for the regulation of metabolic, structural and biochemical functions in organisms $[20,22,26]$.

Table V

Major mineral contents in maize beverage samples

\begin{tabular}{|c|c|c|c|c|c|c|}
\hline \multirow{2}{*}{ Treatment } & \multicolumn{6}{|c|}{ Major elements $(\mathrm{mg} / \mathrm{L})$} \\
\hline & $\mathrm{Ca}$ & $\mathrm{Mg}$ & $\mathrm{K}$ & $\mathrm{Na}$ & $\mathrm{P}$ & $\mathrm{S}$ \\
\hline Control & $209.65 \pm 2.29^{\mathrm{a}}$ & $34.84 \pm 0.14^{\mathrm{a}}$ & $129.60 \pm 16.70^{\mathrm{a}}$ & $254.27 \pm 10.41^{\mathrm{a}}$ & $169.60 \pm 8.51^{\mathrm{a}}$ & $86.53 \pm 1.30^{\mathrm{a}}$ \\
\hline $63^{\circ} \mathrm{C}, 30 \mathrm{~min}$ & $189.55 \pm 10.68^{\mathrm{a}}$ & $38.71 \pm 5.58^{\mathrm{a}}$ & $100.52 \pm 1.48^{\mathrm{a}}$ & $226.57 \pm 1.02^{b}$ & $145.74 \pm 4.53^{\mathrm{a}}$ & $91.73 \pm 0.57^{\mathrm{a}}$ \\
\hline $73^{\circ} \mathrm{C}, 15 \mathrm{~min}$ & $206.15 \pm 1.51^{\mathrm{a}}$ & $41.03 \pm 0.27^{\mathrm{a}}$ & $97.89 \pm 34.02^{\mathrm{a}}$ & $219.24 \pm 5.24^{b c}$ & $149.39 \pm 7.15^{\mathrm{a}}$ & $87.41 \pm 0.21^{\mathrm{a}}$ \\
\hline $85^{\circ} \mathrm{C}, 5 \mathrm{~min}$ & $204.96 \pm 6.42^{\mathrm{a}}$ & $37.58 \pm 1.26^{\mathrm{a}}$ & $97.39 \pm 3.49^{\mathrm{a}}$ & $200.43 \pm 1.32^{c}$ & $160.97 \pm 16.77^{\mathrm{a}}$ & $83.76 \pm 5.08^{a}$ \\
\hline
\end{tabular}

Table VI

Minor mineral contents in maize beverage samples

\begin{tabular}{lcccc}
\hline \multirow{2}{*}{ Treatment } & \multicolumn{4}{c}{ Minor elements $(\mathrm{mg} / \mathrm{L})$} \\
\cline { 2 - 5 } & $\mathrm{Mn}$ & $\mathrm{Cu}$ & $\mathrm{Zn}$ & $\mathrm{Fe}$ \\
\hline Control & $0.28 \pm 0.021^{\mathrm{ab}}$ & $0.34 \pm 0.009^{\mathrm{a}}$ & $0.72 \pm 0.095^{\mathrm{a}}$ & $3.87 \pm 0.22^{\mathrm{a}}$ \\
$63^{\circ} \mathrm{C}, 30 \mathrm{~min}$ & $0.15 \pm 0.013^{\mathrm{b}}$ & $0.26 \pm 0.006^{\mathrm{ab}}$ & $0.57 \pm 0.048^{\mathrm{a}}$ & $2.96 \pm 0.48^{\mathrm{a}}$ \\
$73^{\circ} \mathrm{C}, 15 \mathrm{~min}$ & $0.19 \pm 0.068^{\mathrm{b}}$ & $0.18 \pm 0.060^{\mathrm{b}}$ & $0.25 \pm 0.029^{\mathrm{b}}$ & $3.64 \pm 0.72^{\mathrm{a}}$ \\
$85^{\circ} \mathrm{C}, 5$ min & $0.36 \pm 0.001^{\mathrm{a}}$ & $0.19 \pm 0.040^{\mathrm{ab}}$ & $0.56 \pm 0.016^{\mathrm{a}}$ & $2.11 \pm 0.34^{\mathrm{a}}$ \\
\hline
\end{tabular}

The different letters in the columns indicate statistical differences $(\mathrm{p} \leq 0.05, \mathrm{n}=3)$.

Total phenols, total flavonoids, condensed tannins, and total anthocyanins

The total phenol content varied from 125.10 to 103.20 $\mathrm{mg}$ GAE/L with statistical differences among thermal treatments. The lowest value was obtained in the control treatment and the highest was obtained in the thermal treatment at $63^{\circ} \mathrm{C}$ for $30 \mathrm{~min}$. The thermal treatments at $73^{\circ} \mathrm{C}$ for $15 \mathrm{~min}$ and $85^{\circ} \mathrm{C}$ for $5 \mathrm{~min}$ showed values of 124.35 and $120.95 \mathrm{mg} \mathrm{GAE} / \mathrm{L}$,

respectively (Table VII). The increase in total phenols was explained by Krings and Berger et al. [17] and Oboh et al. [23], who mentioned that the Maillard reaction causes the formation of high molecular weight compounds, such as melanoidins, thereby increasing the detection of total phenols $[27,36]$, but the thermal treatments can also release bound phenolics which can increase the antioxidant capacity [31].

Table VII

Content of phenolic compounds in maize beverage samples

\begin{tabular}{llccc}
\hline \multirow{2}{*}{ Treatment } & \multicolumn{4}{c}{ Phenolic group (mg/L) $^{*}$} \\
\cline { 2 - 5 } & Total phenols $^{*}$ & Total flavonoids $^{* *}$ & Condensed tannins $^{* *}$ & Total anthocyanins $^{* * *}$ \\
\hline Control & $103.20 \pm 2.14^{\mathrm{b}}$ & $53.14 \pm 4.11 \mathrm{~b}$ & $\mathrm{ND}$ & $1.09 \pm 0.09^{\mathrm{a}}$ \\
$63^{\circ} \mathrm{C}, 30 \mathrm{~min}$ & $125.10 \pm 1.95^{\mathrm{a}}$ & $62.31 \pm 4.59^{\mathrm{ab}}$ & $\mathrm{ND}$ & $1.16 \pm 0.11^{\mathrm{a}}$ \\
$73^{\circ} \mathrm{C}, 15 \mathrm{~min}$ & $124.35 \pm 2.08^{\mathrm{a}}$ & $62.03 \pm 2.55^{\mathrm{ab}}$ & $\mathrm{ND}$ & $1.25 \pm 0.17^{\mathrm{a}}$ \\
$85^{\circ} \mathrm{C}, 5 \mathrm{~min}$ & $120.95 \pm 4.36^{\mathrm{a}}$ & $70.36 \pm 3.37^{\mathrm{a}}$ & ND & $1.32 \pm 0.11^{\mathrm{a}}$ \\
\hline
\end{tabular}

The different letters in the columns indicate statistical differences $(\mathrm{p} \leq 0.05)$. Values are shown as mean \pm standard deviation. ${ }^{*} \mathrm{mg}$ GAE/L,

${ }^{* * *} \mathrm{mg} \mathrm{CatE} / \mathrm{L},{ }^{* * *} \mathrm{mg} \mathrm{C} 3 \mathrm{GE} / \mathrm{L}, \mathrm{ND}=$ not detected.

As for the total flavonoid concentration, values varied from 70.36 to $53.14 \mathrm{mg}$ CatE/L. The lowest value was found in the beverage without thermal treatment and the highest value was found following the $85^{\circ} \mathrm{C}, 5 \mathrm{~min}$ treatment. It should be noted that thermal processes had a positive effect on total flavonoid identification in the beverage because the content increased as the temperature of thermal treatment increased (Table VII). This increment in total flavonoids could be explained by results of Caristi et al. [5] and Gattuso et al. [12] 
FARMACIA, 2019, Vol. 67, 4

who mentioned that flavonoids can be found in a glycosylated form, which prevents their detection by common spectrophotometric methods. Condensed tannins were not identified in any of the treatments. The total anthocyanin content ranged from 1.32 $\left(85^{\circ} \mathrm{C}, 5 \mathrm{~min}\right.$ ) to 1.09 (control) $\mathrm{mg} \mathrm{C} 3 \mathrm{GE} / \mathrm{L}$, but no statistical differences were found among the treatments (Table VII). The total anthocyanins results could be attributed to the low maize flour concentration in the prepared beverage; however, despite the dilution, they were quantified at low concentrations. These results differ from those reported by Harbourne et al. [13] and Mishra et al. [21] who mentioned that anthocyanins present in beverages formulated from anthocyanin-rich products degrade faster with a greater heat treatment temperature.

High Performance Liquid Chromatography (HPLC) Analysis of Phenolics

Regarding the phenolics analysis by HPLC, chlorogenic acid was only detected in the control treatment with a value of $37.14 \mathrm{mg} / \mathrm{L}$. On the other hand, caffeic acid was not detected in the control treatment, but it was detected in all thermal treatments with values ranging from $33.26\left(85^{\circ} \mathrm{C}, 5 \mathrm{~min}\right)$ to $27.93\left(63^{\circ} \mathrm{C}, 30 \mathrm{~min}\right)$ $\mathrm{mg} / \mathrm{L}$, and statistical differences $(\mathrm{p} \leq 0.05)$ were found

among treatments (Table VIII) (Figure 1). The changes in the caffeic acid content correlated with the temperature; as the temperature increased, the caffeic content also increased. From the results obtained, a relationship between the loss of chlorogenic acid in the samples and thermal treatment can be deduced, because chlorogenic acid is the result of an esterification of caffeic acid with quinic acid [24, 18], and the ester linkage can be broken by thermal treatment, as described by Variyar et al. [37].

This behaviour may explain why chlorogenic acid was only detected in the control sample and caffeic acid was detected in all the thermal treated samples. In addition, there was a higher concentration of caffeic acid as the temperature of the treatment increased.

Ferulic acid was detected in all treatments, with statistical differences $(p \leq 0.05)$ among treatments (Table VIII) (Figure 1). Values were from $40.57\left(85^{\circ} \mathrm{C}\right.$, $5 \mathrm{~min})$ to $34.70\left(73^{\circ} \mathrm{C}, 15 \mathrm{~min}\right) \mathrm{mg} / \mathrm{L}$. These results indicate that as the temperature of the sterilization process increased, it also increased the release of ferulic acid from the structure of the cell wall or other glycosylated compounds, as was previously described by Saulnier et al. [33] and Kim et al. [16].

Table VIII

Phenolic compounds determined by HPLC analysis in maize beverage samples

\begin{tabular}{|c|c|c|c|c|}
\hline \multirow{2}{*}{ Treatment } & \multicolumn{3}{|c|}{ Phenolic compound (mg/L) } & \multirow{2}{*}{ Total } \\
\hline & Chlorogenic acid & Caffeic acid & Ferulic acid & \\
\hline Control & $37.14 \pm 3.77^{\mathrm{a}}$ & ND & $36.46 \pm 0.55^{b}$ & 73.60 \\
\hline $63^{\circ} \mathrm{C}, 30 \mathrm{~min}$ & ND & $27.93 \pm 1.98^{\mathrm{b}}$ & $35.72 \pm 2.05^{\mathrm{b}}$ & 63.65 \\
\hline $73^{\circ} \mathrm{C}, 15 \mathrm{~min}$ & ND & $29.38 \pm 0.79^{b}$ & $34.70 \pm 1.95^{b}$ & 64.08 \\
\hline $85^{\circ} \mathrm{C}, 5 \mathrm{~min}$ & ND & $33.26 \pm 0.44^{\mathrm{a}}$ & $40.57 \pm 0.68^{\mathrm{a}}$ & 73.83 \\
\hline
\end{tabular}

The different letters in the columns indicate statistical differences $(\mathrm{p} \leq 0.05, \mathrm{n}=3)$. ND $=$ not detected.

DPPH, ABTS, and FRAP antioxidant capacity The antioxidant capacity, as determined by DPPH (Table IX), in beverages ranged from 384.78 to $312.00 \mu \mathrm{mol} \mathrm{TE} / \mathrm{L}$, with the $85^{\circ} \mathrm{C}, 5 \mathrm{~min}$ treatment and the control having the highest and the lowest values, respectively, with statistical differences $(\mathrm{p} \leq$ 0.05 ) among treatments. These outcomes may be explained by the results found by Tacora et al. [36] and Pérez-Hernández et al. [27] who mentioned that products generated in the Maillard reaction result from thermal treatment.

The antioxidant capacity results measured by ABTS assay also showed statistical differences $(p \leq 0.05)$ among treatments, with values that ranged from 527.91 to $449.30 \mu \mathrm{mol} \mathrm{TE} / \mathrm{L}$. The lowest value was observed in the $85^{\circ} \mathrm{C}, 5 \mathrm{~min}$ treatment, and the highest value was observed in the control treatment. The ABTS results for the maize beverage showed that increasing the temperature of the thermal treatment decreased the antioxidant capacity (Table IX). This change is the result of several factors that affect phenolic compounds; several authors have mentioned that phenolic compounds are easily oxidized during food preparation processes, as $\mathrm{pH}$, light, metal ions, temperature, oxygen and sugar might influence the content of other compounds, including those with the ability to release electrons $[14,25,28,29,30]$.

Table IX

Antioxidant capacity of maize beverage samples

\begin{tabular}{lccc}
\hline \multirow{2}{*}{ Treatment } & \multicolumn{3}{c}{ Antioxidant capacity $(\mu \mathrm{mol}$ TE/L) } \\
\cline { 2 - 4 } & DPPH & ABTS & FRAP \\
\hline Control & $312.00 \pm 11.67^{\mathrm{b}}$ & $519.30 \pm 5.84^{\mathrm{a}}$ & $1093.33 \pm 85.20^{\mathrm{b}}$ \\
$63^{\circ} \mathrm{C}, 30 \mathrm{~min}$ & $360.89 \pm 10.72^{\mathrm{a}}$ & $455.97 \pm 20.68^{\mathrm{b}}$ & $1478.33 \pm 58.38^{\mathrm{a}}$ \\
$73^{\circ} \mathrm{C}, 15 \mathrm{~min}$ & $313.11 \pm 9.18^{\mathrm{b}}$ & $478.09 \pm 14.29^{\mathrm{ab}}$ & $1530.00 \pm 13.23^{\mathrm{a}}$ \\
$85^{\circ} \mathrm{C}, 5$ min & $384.78 \pm 6.31^{\mathrm{a}}$ & $449.30 \pm 12.34^{\mathrm{b}}$ & $1566.67 \pm 80.36^{\mathrm{a}}$ \\
\hline columns indicate statistical differences $(\mathrm{p} \leq 0.05, \mathrm{n}=3)$ &
\end{tabular}



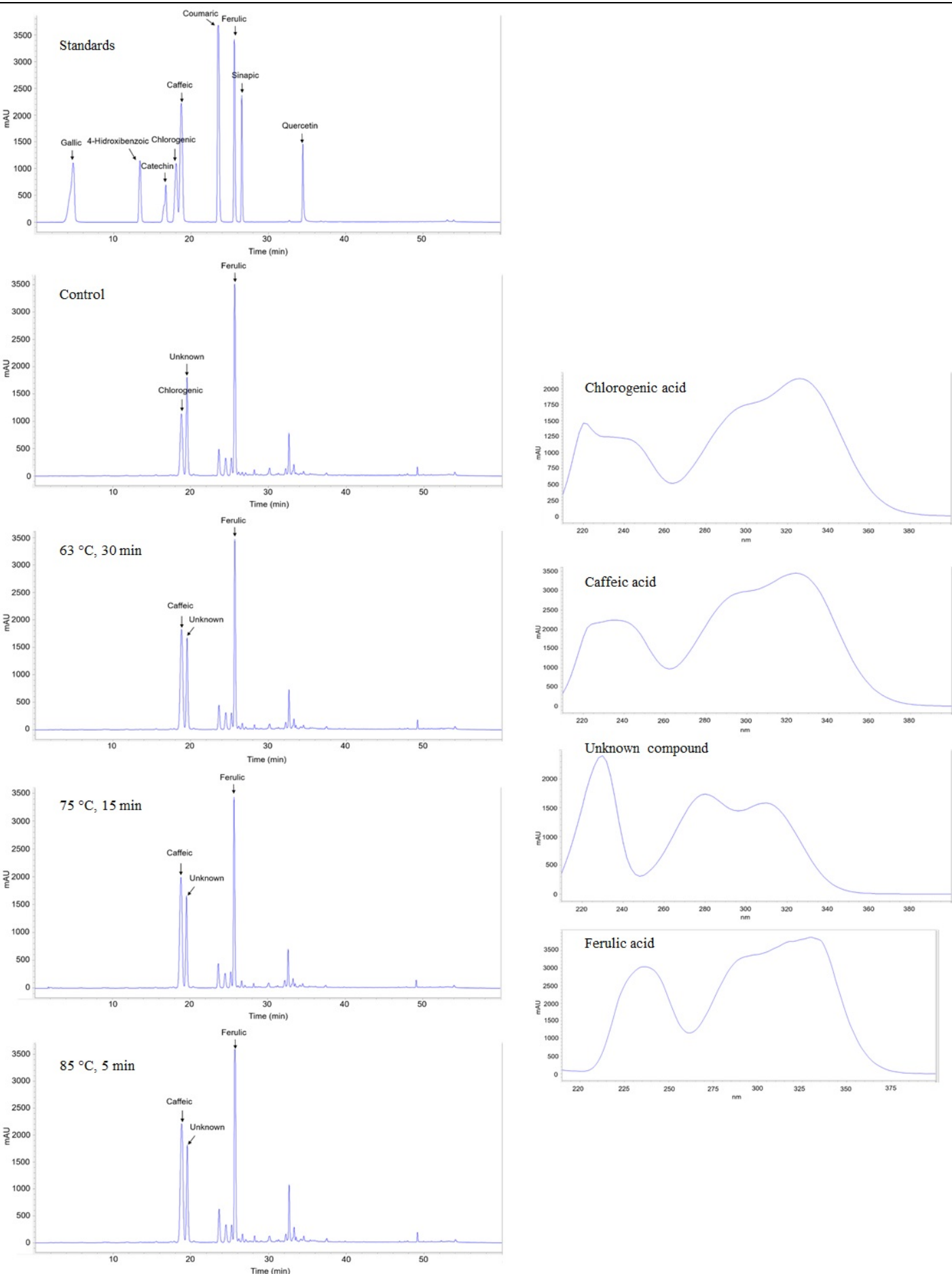

Figure 1.

Chromatograms and spectra of phenolic compounds identified by HPLC in maize beverage samples

Results for the FRAP antioxidant capacity showed statistical differences $(p \leq 0.05)$ with values that varied from 1093 to $1566.67 \mu \mathrm{mol} \mathrm{TE} / \mathrm{L}$. Lower results were obtained in the control beverage, and higher results were obtained in the case of heat treatments $(63,73$ and $85^{\circ} \mathrm{C}$ ); an increase of ferric ion reduction occurred as the temperature increased (Table IX). The increase of the antioxidant capacity detected by the FRAP method was explained by Krings and Berger [17], Kim et al. [16], and Oboh et al. [23], who reported that after a thermal process, the antioxidant capacity increased and $\mathrm{Fe}^{+3} / \mathrm{Fe}^{+2}$ ferric ion reduction improved. This behaviour was attributed to the synergism of phytochemicals and the melanoidins, produced by Maillard reaction. However, in this evaluation of antioxidant capacity, the results obtained differ from those reported by Rhim [29] and Patras et al. [25] who stated that sugar can cause the oxidation of phenolic compounds. 


\section{Conclusions}

The results showed that the thermal treatment has no effect on the organoleptic characteristics, the concentration of soluble solids, the $\mathrm{pH}$, or the titratable acidity of a roasted purple maize beverage. The thermal treatment was efficient of eliminating microorganisms that can accelerate the deterioration of the beverage. The beverage developed for this research is an excellent source of essential minerals. Additionally, it was found that its content of phenolic compounds and its antioxidant capacity increased following the heat treatment.

\section{References}

1. Abdel Aal ESM, Hucl P, A rapid method for quantifying total anthocyanins in blue aleurone and purple pericarp wheats. Cereal Chem., 1999; 76(3): 350-354.

2. Ajandouz EH, Tchiakpe LS, Dalle Ore F, Benajiba A, Puigserver A, Effects of $\mathrm{pH}$ on caramelization and Maillard reaction kinetics in fructose lysine model systems. J Food Sci., 2001; 66(7): 926-931.

3. Association of Official Analytical Chemist (AOAC), Official Methods of Analysis of AOAC International, 1998; Rockville, MD, USA, $16^{\text {th }}$ edition.

4. Bello-Pérez LA, Camelo-Méndez GA, Agama-Acevedo E, Utrilla-Coello RG, Nutraceutical aspects of pigmented maize: digestibility of carbohydrates and anthocyanins. Agrociencia, 2016; 50(8): 1041-1063 (available in Spanish).

5. Caristi C, Bellocco E, Gargiulli C, Toscano G, Leuzzi $\mathrm{U}$, Flavone-di-C-glycosides in citrus juices from Southern Italy. Food Chem., 2006; 95(3), 431-437.

6. ColorHexa, Color Encyclopedia: Information and Conversion: Comp. Software, 2017; www.colorhexa.com.

7. Commission Internationale De L'ecleirage, Cie 15: Technical Report: Colorimetry, Commission Internationale De L'ecleirage, 2004; Vienna, Austria, $3^{\text {rd }}$ edition.

8. Corbo MR, Bevilacqua A, Petruzzi L, Casanova FP, Sinigaglia M, Functional beverages: the emerging side of functional foods. Compr Rev Food Sci F., 2014; 13(6): 1192-1206.

9. Cortés C, Esteve MJ, Frígola A, Color of orange juice treated by high intensity pulsed electric fields during refrigerated storage and comparison with pasteurized juice. Food Control, 2008; 19(2): 151-158.

10. Das A, Raychaudhuri U, Chakraborty R, Cereal based functional food of Indian subcontinent: a review. J Food Sci Tech Mys., 2012; 49(6): 665-672.

11. Escalante-Aburto A, Ramírez-Wong B, Torres-Chávez PI, Barrón-Hoyos JM, Figueroa-Cárdenas JD, LópezCervantes J, The nixtamalization and its effect on the anthocyanin content of pigmented maize, a review. Rev Fitotec Mex., 2013; 36: 429-437 (available in Spanish).

12. Gattuso G, Barreca D, Gargiulli C, Leuzzi U, Caristi C, Flavonoid composition of citrus juices. Molecules, 2007; 12(8): 1641-1673.

13. Harbourne N, Jacquier JC, Morgan DJ, Lyng JG, Determination of the degradation kinetics of anthocyanins in a model juice system using isothermal and non-isothermal methods. Food Chem., 2008; 111(1): 204-208.

14. Jang JH, Moon KD, Inhibition of polyphenol oxidase and peroxidase activities on fresh-cut apple by simultaneous treatment of ultrasound and ascorbic acid. Food Chem., 2011; 124(2): 444-449.

15. Kato TA, Mapes C, Mera LM, Serratos JA, Bye RA, Origin and diversification of corn: an analytical review. National Autonomous University Mexico. National Commission for the Knowledge and Use of Biodiversity, 2009; México DF, México: 116 (available in Spanish).

16. Kim KH, Tsao R, Yang R, Cui SW, Phenolic acid profiles and antioxidant activities of wheat bran extracts and the effect of hydrolysis conditions. Food Chem., 2006; 95(3): 466-473.

17. Krings U, Berger RG, Antioxidant activity of some roasted foods. Food Chem., 2001; 72(2): 223-229.

18. Lafay S, Morand C, Manach C, Besson C, Scalbert A, Absorption and metabolism of caffeic acid and chlorogenic acid in the small intestine of rats. Brit J Nutr., 2006; 96(1): 39-46.

19. Lopez-Contreras JJ, Zavala-Garcia F, Urias-Orona V, Martinez-Avila GCG, Rojas R, Niño-Medina G, Chromatic, phenolic and antioxidant properties of Sorghum bicolor genotypes. Not Bot Horti Agrobo., 2015; 43(2): 366-370.

20. Mir-Marqués A, Cervera ML, de la Guardia M, A preliminary approach to mineral intake in the Spanish diet established from analysis of the composition of university canteen menus. J Food Compos Anal., 2012; 27(2): 160-168.

21. Mishra DK, Dolan KD, Yang L, Confidence intervals for modeling anthocyanin retention in grape pomace during nonisothermal heating. J Food Sci., 2008; 73(1): E9-E15.

22. Obinna-Echem PC, Beal J, Kuri V, Effect of processing method on the mineral content of Nigerian fermented maize infant complementary food - Akamu. LWTFood Sci Technol., 2015; 61(1): 145-151.

23. Oboh G, Ademiluyi AO, Akindahunsi AA, The effect of roasting on the nutritional and antioxidant properties of yellow and white maize varieties. Int $J$ Food Sci Tech., 2010; 45(6): 1236-1242.

24. Olthof MR, Hollman PC, Katan MB, Chlorogenic acid and caffeic acid are absorbed in humans. $J$ Nutr., 2001; 131(1): 66-71.

25. Patras A, Brunton NP, O'Donnell C, Tiwari BK, Effect of thermal processing on anthocyanin stability in foods; mechanisms and kinetics of degradation. Trends Food Sci Tech., 2010; 21(1): 3-11.

26. Pedro NAR, de Oliveira E, Cadore S, Study of the mineral content of chocolate flavoured beverages. Food Chem., 2006; 95(1): 94-100.

27. Pérez-Hernández LM, Chávez-Quiroz K, MedinaJuárez LA, Gámez-Meza N, Phenolic characterization, melanoidins, and antioxidant activity of some commercial coffees from Coffea arabica and Coffea canephora. J Mex Chem Soc., 2012; 56(4): 430-435.

28. Rawson A, Patras A, Tiwari BK, Noci F, Koutchma $\mathrm{T}$, Brunton N, Effect of thermal and non thermal processing technologies on the bioactive content of exotic fruits and their products: review of recent advances. Food Res Int., 2011; 44(7): 1875-1887. 
29. Rhim JW, Kinetics of thermal degradation of anthocyanin pigment solutions driven from red flower cabbage. Food Sci Biotechnol., 2002; 11(4): 361-364.

30. Rico D, Martin-Diana AB, Barat JM, Barry-Ryan $\mathrm{C}$, Extending and measuring the quality of fresh-cut fruit and vegetables: a review. Trends Food Sci Tech., 2007; 18(7): 373-386.

31. Rusu ME, Gheldiu AM, Mocan A, Vlase L, Popa DS, Anti-aging potential of tree nuts with a focus on the phytochemical composition, molecular mechanisms and thermal stability of major bioactive compounds. Food Funct, 2018; 9(5): 2554-2575.

32. Santos J, Oliveira MBPP, Ibáñez E, Herrero M, Phenolic profile evolution of different ready-to-eat baby-leaf vegetables during storage. $J$ Chromatogr A, 2014; 1327: 118-131.

33. Saulnier L, Marot C, Elgorriaga M, Bonnin E, Thibault $\mathrm{JF}$, Thermal and enzymatic treatments for the release of free ferulic acid from maize bran. Carbohyd Polym., 2001; 45(3): 269-275.

34. Serna-Saldívar SO, Gutiérrez-Uribe JA, Mora-Rochin S, García-Lara S, Nutraceutical potential of the criollo maize and changes during the traditional processing and with extrusion. Rev Fitotec Mex., 2013; 36(3A): 295-304 (available in Spanish).

35. Suárez-Jacobo A, Gervilla R, Guamis B, Roig-Sagués AX, Saldo J, Effect of UHPH on indigenous microbiota of apple juice: a preliminary study of microbial shelflife. Int J Food Microbiol., 2010; 136(3): 261-267.
36. Tacora Cauna RL, Luna Mercado GI, Bravo Portocarrero R, Mayta Hancco J, Choque Yucra M, Ibañez Quispe $\mathrm{V}$, Effect of the pressure of expansion by explosion and temperature of toasting in some functional and physicochemical characteristics of two varieties of cañihua (Chenopodium pallidicaule Aellen). Journal de Ciencia y Tecnología Agraria, 2010; 2(1): 188198, (available in Spanish).

37. Variyar PS, Ahmad R, Bhat R, Niyas Z, Sharma A, Flavoring components of raw monsooned arabica coffee and their changes during radiation processing. J Agr Food Chem., 2003; 51(27): 7945-7950.

38. Vitaglione P, Napolitano A, Fogliano V, Cereal dietary fibre: a natural functional ingredient to deliver phenolic compounds into the gut. Trends Food Sci Technol., 2008; 19(9): 451-463

39. Yusof S, Chiong LK, Effects of Brix, processing techniques and storage temperature on the quality of carambola fruit cordial. Food Chem., 1997; 59(1): 27-32.

40. Zhao Z, Egashira Y, Sanada H, Phenolic antioxidants richly contained in corn bran are slightly bioavailable in rats. J Agr Food Chem., 2005; 53(12): 5030-5035.

41. Zulueta A, Barba FJ, Esteve MJ, Frígola A, Changes in quality and nutritional parameters during refrigerated storage of an orange juice-milk beverage treated by equivalent thermal and non-thermal processes for mild pasteurization. Food Bioprocess Tech., 2013; 6(8): 2018-2030. 